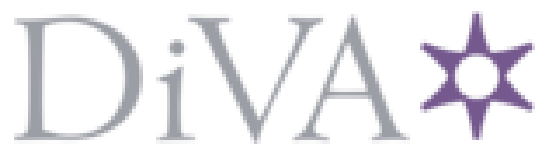

http://www.diva-portal.org

This is the published version of a chapter published in Festskrift till Örjan Edström.

Citation for the original published chapter:

Derlén, M., Lindholm, J. (2019)

What happened to the revolution?: one decade with Trailers and MEQRs

In: Ruth Mannelqvist, Staffan Ingmanson, Carin Ulander-Wänman (ed.), Festskrift till

Örjan Edström (pp. 91-108). Umeå: Department of Law, Umeå University

N.B. When citing this work, cite the original published chapter.

Permanent link to this version:

http://urn.kb.se/resolve?urn=urn:nbn:se:umu:diva-160259 


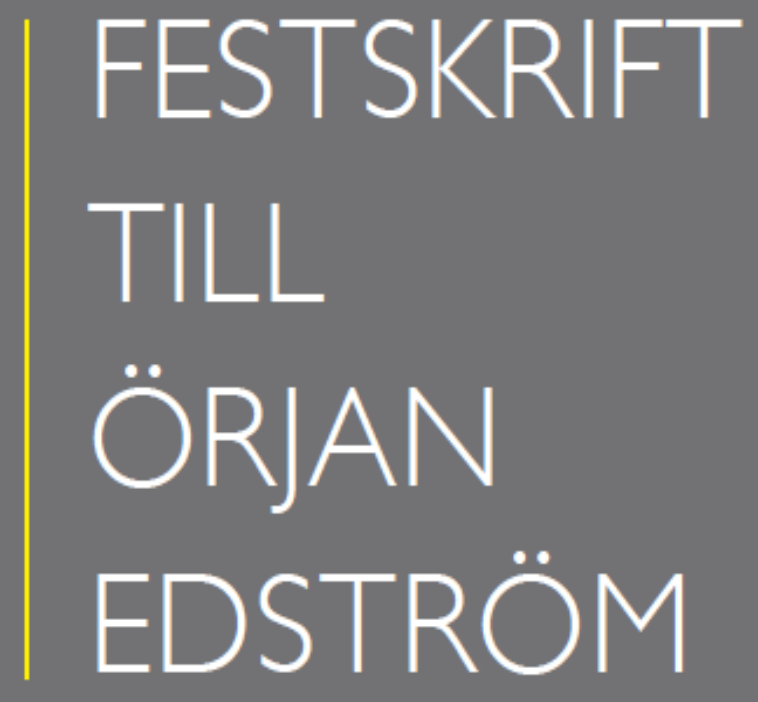

$\begin{array}{r}\text { Skrifter från juridiska institutionen } \\ \text { vid Umeå universitet }\end{array} /$ I 


\title{
What Happened to the Revolution? \\ One Decade with Trailers and MEQRs
}

\author{
MATTIAS DERLÉN \& JOHAN LINDHOLM ${ }^{1}$
}

\section{Introduction}

Many important European historic events originated in Italy, including religious, cultural and political developments. Italy's importance holds true also when it comes to the law, as the Roman legal system has constituted the basis of much of continental European law. The Italian legislation banning the use of trailers with motorcycles might appear prosaic against this historical background. However, it is not the first time that seemingly minor events in Italy have shaped the course of the European Union. Who would have guessed that the refusal to pay an electrical bill would give rise to the principle of supremacy of $\mathrm{EU}$ law, ${ }^{2}$ that the nonimplementation of a directive would lead to the creation of the principle of state liability ${ }^{3}$ or that the question whether wool was an animal product would result in the most infamous decision concerning preliminary rulings? ${ }^{4}$

In response to Italy banning use of motorcycle trailers, the Court of Justice of the European Union (CJEU) delivered its judgment in the so-called Trailers case in February 2009. ${ }^{5}$ In the judgment, the CJEU offered a new perspective on the enigmatic ban on measures having an equivalent effect to a quantitative restrictions (MEQRs) in Article 34 of the Treaty on the Functioning of the European Union (TFEU). For this reason, we welcomed the Court's decision in Trailers when it was first delivered as a positive, even necessary, development in an area fraught with

\footnotetext{
${ }^{1}$ Professors of Law at the Department of Law at Umeå University.

${ }^{2}$ Case 6/64, Costa v. E.N.E.L., EU:C:1964:66.

${ }^{3}$ Joined Cases C-6/90 \& C-9/90, Francovich \& Bonifaci et al. v. Italy, EU:C:1991:428.

${ }^{4}$ Case 283/81, Srl CILFIT \& Lanificio di Gavardo SpA v. Ministry of Health, EU:C:1982:335.

${ }^{5}$ Case C-110/05, Commission v. Italy, EU:C:2009:66 (henceforth Trailers).
} 
complications. ${ }^{6}$ However, we also noted that the case left us with many questions as to the future direction of the CJEU. Commission v. Italy was an opportunity for the CJEU to clean house with regard to its case law on MEQRs, but it remained to be seen whether the CJEU would seize this opportunity. One decade on, and after several notable judgments, we are now in a position to return to those questions and to make some conclusion as to the continued relevance of the seminal cases Dassonville, Cassis de Dijon and Keck. ${ }^{7}$

\section{Trailers - A Summary}

The Trailers case concerned an Italian ban on motorcycle trailers. However, the legislation in question did not ban the import or sale of the trailers, only their use. This only seemed to occur to the Court rather late in the process. The case started out in the third chamber, with no oral argument and with an opinion given by Advocate General Léger. However, instead of issuing a judgment the third chamber decided to refer the case back to the Court to be decided by the Grand Chamber. ${ }^{8}$ The Grand Chamber then re-opened the oral argument and invited the Member States to make their positions known on the applicability of Article 34 TFEU to rules on use, such as those in question. ${ }^{9}$ Obviously, the third chamber, as well as the Grand Chamber, found that rules on use constituted a new category, whose inclusion as MEQRs merited further discussion. This is somewhat odd, given that it was far from the first time that the CJEU treated a rule on use as an MEQR. ${ }^{10}$ While this amnesia on the part of the Court is surprising, it served as an opportunity to revisit and clarify its case law on MEQRs. After referring to Dassonville, Cassis and Keck, the Court offered a new, three-part definition of when national measures constitute MEQRs that distinguishes between (1) discriminatory rules, (2) product requirements and (3) other obstacles to market access. ${ }^{11}$ Advocate General Bot has since referred to this as the "standard formula" used by the Court in its Article 34

\footnotetext{
${ }^{6}$ Mattias Derlén \& Johan Lindholm, “Article 28 E.C. and Rules on Use: A Step Towards a Workable Doctrine on Measures Having Equivalent Effect to Quantitative Restrictions”, Columbia Journal of European Law vol. 16(2) pp. 191-231 (2010).

${ }^{7}$ Case 8/74, Procureur du Roi v. Dassonville, EU:C:1974:82; Case 120/78, Rewe-Zentral AG v. Bundesmonopolverwaltung für Branntwein (Cassis de Dijon), EU:C:1979:42; Joined cases C-267/91 \& C-268/91, Criminal proceedings against Keck \& Mithouard, EU:C:1993:905.

8 Trailers, paras. 13-14.

${ }^{9}$ Ibid., para. 15.

${ }^{10}$ Case C-473/98, Kemikalieinspektionen v. Toolex Alpha AB, EU:C:2000:379; C-265/06, Commission v. Portugal, EU:C:2008:210.

11 Trailers, para. 37.
} 
case law. ${ }^{12}$ The Court implies that this definition follows from the previous cases, but it has the potential to consolidate and simplify the approach to MEQRs. We argued that there are numerous advantages to this new test: ${ }^{13}$

1. The definition of MEQRs in Dassonville, in many ways the original sin, can finally be left behind. Its extensive, all-encompassing definition has created all manner of problems and can be abandoned in favour of the three-part definition of MEQRs introduced in Trailers.

2. Instead of choosing either a discrimination or a market access approach, Trailers combined the approaches, creating a test where relatively straightforward situations (discriminatory measures and product requirements) are classified as MEQRs directly, saving the more complex market access test for other, more difficult situations.

3. The complex - and arguably fundamentally flawed - discrimination analysis in Keck can finally be dispatched. As it turned out, selling arrangements are not unique. The three-part test handles selling arrangements together with rules on use and all other measures that are neither discriminatory nor product requirements. Consequently, while we still need Cassis (product requirements), we do not need Keck (selling arrangements).

However, a number of questions remained after Trailers:

1. Would the new, three-part definition of MEQRs be generally applicable, or confined to rules on use and similar "exotic" rules? While the wording and structure of Trailers imply that the test is general, the impression lingers that it does not affect the separate doctrine for selling arrangements created in Keck.

2. What does the discrimination test, the first part of the three-part definition, entail? We have argued in favour of limiting the test to direct discrimination, i.e. distinctly applicable rules, to avoid overlap with the second and third leg of the definition, ${ }^{14}$ but how will the test be administered in practice by the CJEU?

\footnotetext{
${ }^{12}$ AG Bot's opinion in Case C-333/14, Scotch Whisky Association, spiritsEUROPE \& Comité de la Communauté économique européenne des Industries et du Commerce des Vins, Vins aromatisés, Vins mousseux, Vins de liqueur et autres Produits de la Vigne (CEEV) v. Lord Advocate \& Advocate General for Scotland, EU:C:2015:527, para. 58.

${ }^{13}$ See further Derlén \& Lindholm 2010, pp. 227-231.

${ }^{14}$ Ibid., pp. 215-217.
} 
3. When does a measure prevent market access? The idea of market access has long been discussed in the EU law context, but we have inadequate practical information on its application. The Court gave very limited guidance on the use of market access in Trailers, as the Italian rule constituted a total ban on use. Consequently, we need significant more information to be able to use the third part of the new definition on MEQRs.

4. Will the issue of justification stabilize to a more normal level, as compared to Trailers and the immediately following cases? We have detected somewhat of a honeymoon for the Member States, giving them a lot of leeway in the justification discussion. ${ }^{15}$ We would expect this to be a temporary deviation and the Court of Justice to return to a stricter level of review as time passes and the novelty of rules on use dissipates.

We will spend the remainder of the article addressing these opportunities and questions raised by Trailers, starting with the future for the seminal cases Dassonville, Cassis and Keck.

\section{Dassonville - A Lingering Formality}

The CJEU made its first serious attempt to define MEQRs in 1974. In Dassonville, a case concerning national legislation requiring imported goods bearing a designation of origin must be accompanied by an official document issued by the government of the exporting Member States, the CJEU formulated the arguably broadest definition of MEQRs conceivable: ${ }^{16}$

All trading rules enacted by member states which are capable of hindering, directly or indirectly, actually or potentially, intra-community trade are to be considered as measures having an effect equivalent to quantitative restrictions.

The Dassonville formula has become redundant with the launch of a new, practical definition of MEQRs in Trailers. In fact, to continue to use the Dassonville formula only creates confusion as its definition of MEQRs is more extensive than the one provided in Trailers: a measure that marginally restricts market access might fall within the former but outside the latter. Such a gap cannot have been intended by the CJEU, as the three-part definition of MEQRs in Trailers is presented as a summary of previous case law, including Dassonville. Consequently, Trailers must be

\footnotetext{
${ }^{15}$ Derlén \& Lindholm 2010, pp. 220-223.

${ }^{16}$ Dassonville, para. 5.
} 
understood as taking its starting point in the Dassonville formula, but the Dassonville formula as adapted through subsequent case law. Even in older (pre-Keck) case law measures with only a very limited or indirect effect on market access were held not to be MEQRs, despite the wording of Dassonville. ${ }^{17}$ Thus, the Dassonville formula should have no independent meaning after Trailers.

However, the CJEU continues to cite the Dassonville formula, even after Trailers. There is no doubt that Dassonville is alive and well. The case is routinely cited as part of an opening statement concerning Article 34 TFEU and MEQRs, often together with other cases as forming "settled case-law". ${ }^{18}$

However, this does not mean that Dassonville is part of the operative discussion concerning the status of the national rule and the precise meaning of Article 34. In fact, it is questionable whether Dassonville has ever been used in such a manner. ${ }^{19}$ The primary function of Dassonville has been and presumably remains political, as it serves to establish the jurisdiction of the CJEU and the wide scope of Article 34 TFEU. However, this is bound to create uncertainty. Take Ker-Optika, to which we will return below, where Dassonville is used in the manner described above, that is in the opening statement (and only there) as "settled case-law". However, in Ker-Optika it is used together with Trailers, as the source for the Dassonville formula. ${ }^{20}$ The Court then moves on to the three-part definition of prohibited measures from Trailers. How can this be reconciled? Both are described as limiting the discretion of the Member States. After setting forth the Dassonville formula, the CJEU first concludes that measures defined by the formula are MEQRs and "on that basis" prohibited by Article 34 TFEU. Immediately after this, the Court sets out the three-part test, describing it as an addition, and concludes that it "is also apparent from settled caselaw that Article 34 reflects the obligation...". The wording, and the continued use

\footnotetext{
${ }^{17}$ See for example Case C-69/88, H. Krantz GmbH \& Co. v. Ontvanger der Directe Belastingen and Netherlands, EU:C:1990:97, para. 11, where a Dutch law, which authorized the collector of taxes to seize goods found on the premises of a taxpayer, even if those goods were from a supplier established in another Member State who had sold them on instalment terms with reservation of title, was not considered an MEQR because its effect on trade was "too uncertain and indirect".

${ }^{18}$ See for example Case C-108/09, Ker-Optika bt v. ÀNTSZ Dél-dunántúli Regionális Intézete, EU:C:2010:725, para. 47; Case C-484/10, Asociación para la Calidad de los Forjados (Ascafor) \& Asociación de Importadores y Distribuidores de Acero para la Construcción (Asidac) v. Administración del Estado and Others, EU:C:2012:113, para. 52; Case C-333/14, Scotch Whisky Association et al. v. The Lord Advocate \& The Advocate General for Scotland, EU:C:2015:845, para. 31; Case C-114/15, Association des utilisateurs et distributeurs de l'agrochimie européenne (Audace) et al., EU:C:2016:813, para. 66; Case C-481/12, UAB “Juvelta” v. VIt "Lietuvos prabavimo rūmai”, para. 16; Case C-221/15, Criminal proceedings against Etablissements Fr. Colruyt NV, EU:C:2016:704, para. 33.

${ }^{19}$ See further Derlén \& Lindholm 2010, pp. 225-226.

${ }^{20}$ Ker-Optika, para. 47.
} 
of Dassonville, is unfortunate, as it indicates a lingering, wider prohibition compared to the one established in Trailers. This has not created any practical problems, as Dassonville is not used in an operative way, but the Court has missed the opportunity to retire Dassonville altogether. Instead, the Court continues to formally salute the grand old man of Article 34 case law, giving a doff of the cap before moving on to the application of the test established in Trailers.

\section{Cassis de Dijon - An Unexpected Challenge}

Trailers clearly challenged two of the three pillars of the pre-2009 case law on MEQRs: Dassonville and Keck. However, the third pillar, Cassis de Dijon and the case law on product requirements, seemed perfectly safe. The Trailers decision confirmed that product requirements would remain part of the definition of MEQRs and we predicted no clouds on the horizon for Cassis de Dijon. In fact, we applauded the continued use of product requirement as part of a workable, practical approach to Article 34. By removing measures that are (relatively) easy to identify (discriminatory rules, product rules) the complex market access test can be saved for the most difficult situations. ${ }^{21}$

Some cases decided after Trailers appear to confirm the continued relevance of Cassis de Dijon, not only quoting the three-part test of Trailers but also applying the mutual recognition requirement when relevant. For example, in Elenca the Court concluded that Italian legislation requiring CE-marking of construction products violated Article 34, as those products were lawfully marketed in other Member States. ${ }^{22}$

However, recent events have somewhat challenged the future of Cassis de Dijon as an independent test. In two of several vehicle-related cases the CJEU examined Polish and Lithuanian rules requiring the steering wheel to be moved on imported vehicles with right-hand steering. ${ }^{23}$ On its face, this kind of rule is a textbook example of product requirements: the rules concern the product itself and require that the product is modified in order to be sold or used. Advocate General Jääskinen agreed, and treated the national rules as product requirements, violating Article 34 TFEU. ${ }^{24}$ The Court agreed, as expected, on the existence of an MEQR and a prima

${ }^{21}$ Derlén \& Lindholm 2010, pp. 224-225.

${ }^{22}$ Case C-385/10, Elenca Srl v. Ministero dell'Interno, EU:C:2012:634, para. 24.

${ }^{23}$ Case C-639/11, Commission v. Poland, EU:C:2014:173; Case C-61/12, Commission v. Lithuania, EU:C:2014:172.

${ }^{24}$ Opinion of Advocate General Jääskinen in Commission v. Poland and Commission v. Lithuania, para. 73, emphasising that a national rule restricting goods lawfully manufactured and marketed in other 
facie violation of Article 34, but chose not to treat the rules as product requirements. Instead, the Court concluded that they restricted market access for vehicles with right-hand steering. This could be seen as an indication that even the product requirement test will have to step aside for a more general market access test. ${ }^{25}$

We certainly would not dismiss this possibility; Commission v. Poland and Commission v. Lithuania might well be a storm crow, announcing the diminishing importance of Cassis de Dijon and the rise of market access. It fits with other, less obvious examples, where the Court could reasonably have used Cassis de Dijon but refrained from doing so. For example, in Ascafor Spanish rules went beyond the minimum standards established by the Union concerning reinforcing steel, requiring goods already approved by other Member States to fulfil further requirements. However, instead of discussing mutual recognition, the Court turned to market access, concluding that the Spanish rules discouraged import and thus constituted an MEQR. ${ }^{26}$

However, it is not yet time to give up on Cassis de Dijon. In particular, Commission v. Poland and Commission v. Lithuania should be read with caution. Importing new vehicles was already subject to harmonization, and it was practically a foregone conclusion that the Court would not allow the same restrictions regarding used vehicles. $^{27}$ The discussion as to the existence of a restriction is thus rather brief. Furthermore, Cassis is cited, despite the emphasis on market access. Similar caveats hold true for Ascafor, where the issue was also closely related to harmonization. There is still the possibility that these cases were aberrations, not the basis for a new doctrine. We argue strongly against giving up Cassis, as this would present unnecessary complications. There is simply no need to discuss whether a product rule restricts market access, it does so per definition. If a product, lawfully produced and marketed in one Member State, cannot be sold in another Member State without

\footnotetext{
Member States constitutes an MEQR. As observed by Lianos, the Advocate General emphasises the disparate impact on imported cars, and that this places them at a disadvantage as compared to domestic production. Ibid., paras. 74-77; Ioannis Lianos, "In Memoriam Keck: the reformation of the EU law on the free movement of goods", European Law Review vol. 40(2) pp. 225-248 (2015), at pp. 235-236. However, we understand this discussion to be part of a product requirement approach, rather than a refusal to classify the relevant rules as product requirements, rules on use or selling arrangements, as argued by Lianos.

${ }^{25}$ Lianos argues that the market access approach by the Court is so broad that it would capture any obstacle to trade, as was the situation before Keck. Lianos 2015, pp. 236-237. This is an interesting discussion, but the abruptness of the reasoning of the Court makes it difficult to evaluate.

26 Ascafor, paras. 52-57.

${ }^{27}$ See further Phil Syrpis, "The Relationship Between Primary and Secondary Law in the EU”, Common Market Law Review vol. 52, pp. 461-488 (2015), at pp. 473-477.
} 
modification, this will restrict market access to a greater or lesser extent. Mutual recognition is a powerful message, one that has no need for market access elaboration. In the same vein, as discussed further in Chapter 6 below, there is no need to equate product rules with discrimination. In many situations product requirements could be seen as de facto discrimination, favouring domestic goods, but again this would be an unnecessary complication. Product rules are problematic in themselves on a free, internal market, we need not worry about whether they are also inherently discriminatory. The beauty of Trailers is that the three legs of the test - non-discrimination, mutual recognition and market access - are separate, as clearly emphasised by the Court in later cases. ${ }^{28}$ Allowing the market access test to consume the other two would be a most unfortunate development, in particular as the market access test is not yet stable. ${ }^{29}$

\section{Keck - Time to Say Goodbye?}

The most obvious challenge in Trailers was to Keck and the idea of selling arrangements. The discussion leading up to the judgment, including the opinions solicited from the Member States and the academic discussion, cantered around whether the preferential treatment of selling arrangements should be extended to rules on use or not. ${ }^{30}$ However, the result was far more interesting, amounting to a fundamental challenge to Keck itself. Selling arrangements are no longer singled out; they are simply one type of measures that must be examined using the market access test. ${ }^{31}$ This is most welcome, as it cuts to the core of what Keck was really about: ensuring market access. Despite using the language of discrimination, the more difficult questions turned on market access. ${ }^{32}$

However, the question remained if the CJEU would follow through and actually give up on Keck, or fall back into old, familiar patterns. The early days post-Trailers indicated the latter. For example, in LIBRO the Court found the national measure to constitute an MEQR based on a traditional application of Keck (discriminatory selling arrangements). ${ }^{33}$ While the CJEU did reference Trailers in LIBRO, it did not

\footnotetext{
28 See for example Ker-Optika, para. 48.

${ }^{29}$ See the discussion in Chapter 7 below.

30 See Derlén \& Lindholm 2010 for further discussion.

31 Unless they are discriminatory in nature.

32 See for example the discussion regarding the Swedish ban on advertising for alcohol in Case C405/98, Konsumentombudsmannen (KO) v. Gourmet International Products AB, EU:C:2001:135.

33 Case C-531/07, Fachverband der Buch- und Medienwirtschaft v. LIBRO Handelsgesellschaft mbH, EU:C:2009:276, para. 20.
} 
mention the part containing the new definition of MEQRs. ${ }^{34}$ As recent as 2015, in $V$ isnapun, the CJEU explicitly relied on Keck and the test laid out therein to analyse whether Finnish legislation requiring that sellers established in other Member States hold a license in order to import alcoholic beverages to Finland. ${ }^{35}$ LIBRO and $V$ isnapun give the impression that Trailers was directed solely at rules on use and other "exotic rules", while Keck and its approach to selling arrangements was unaffected.

However, other CJEU decisions cast doubt on this. The CJEU provided a more nuanced picture in Ker-Optika. The case concerned national rules prohibiting the sale of contact lenses over the Internet, the kind of rule that has typically been deemed a selling arrangement. ${ }^{36}$ The Court discussed Keck, concluding that the national rule was not de jure discriminatory but, by depriving exporters of a particularly useful channel of distribution, constituted de facto discrimination. ${ }^{37}$ More interesting is the part where the Court noted that selling arrangements that are neither de jure nor de facto discriminatory under Keck ${ }^{38}$ do not hinder market access as defined by Trailers. ${ }^{39}$ Thus, the Court has (somewhat belatedly) explained the silence on selling arrangements in Trailers. The market access test and the de facto discrimination test are substitutes. From the direction of Keck this actually follows directly from its sadly neglected paragraph 17, stating that non-discriminatory selling arrangements will, by their very nature, not hinder market access.

More recently, the CJEU appears to have abandoned Keck and the special status it affords to selling arrangements. One example of this is Scotch Whiskey. Through legislation a minimum price per unit (MPU) of alcohol that all licensed retailers had to observe had been implemented in Scotland. A rule like the one examined in Scotch Whiskey, that govern selling prices and that apply equally to all goods and traders regardless of origin, constitutes a selling arrangement under Keck. In fact, this was the type of measure examined in Keck itself. However, the CJEU did not follow or cite Keck. Instead, the Court cited Trailers, and other CJEU decisions that are based

\footnotetext{
${ }^{34}$ Ibid., para. 17.

${ }^{35}$ Case C-198/14, Visnapuu v. Kihlakunnansyyttäjä (Helsinki) \& Suomen valtio - Tullihallitus, EU:C:2015:751, para. 103. That remains however the most recent instance of the CJEU referring to Keck.

${ }^{36}$ See for example Case C-322/01, Deutscher Apothekerverband eV v. 0800 DocMorris NV \& Waterval, EU:C:2003:664, paras. 66-76.

${ }^{37}$ Ker-Optika, paras. 52-56.

${ }^{38}$ Keck, para. 16.

${ }^{39}$ Ker-Optika, para. 51.
} 
upon it, and assessed whether the measure constituted an MEQR using a market access analysis. ${ }^{40}$

A second example is Colruyt where a Belgian corporation contrary to Belgian regulations was selling tobacco products at prices lower than those indicated on the revenue stamp. The national court having jurisdiction over the subsequent criminal proceeding asked the CJEU to clarify whether the national regulation constituted an MEQR. Considering that the facts in Colmyt are very similar to those in Keck, it would be obvious for the Court to use the latter decision as the basis for its response. However, Keck does not appear anywhere in Colruyt. Instead, the CJEU relies heavily on Trailers, concluding that the measure is neither discriminatory nor a product requirement and therefore proceeds to consider whether the rules hindered products originating in other Member States from accessing the Belgian market. ${ }^{41}$ Although the CJEU uses the term "selling arrangements" to describe the Belgian regulations, it does in fact apply the test laid out in Trailers.

The measures examined in Scotch Whiskey and Colruyt fall squarely under Keck, ${ }^{42}$ and there is little doubt that the CJEU would have relied on that decision and the test laid out therein to resolve these cases pre-Trailers. The fact that it did not do so must be interpreted as a conscious effort on behalf of the Court to abandon Keck in favour of the approach established in Trailers. Indeed, it is quite possible that Keck itself would be decided differently if it appeared before the Court after these decisions. ${ }^{43}$

\section{What Discrimination?}

The aspect of MEQRs perhaps most overlooked in the discussion is the ban on discriminatory rules. This aspect of the MEQR definition might appear simple and uncontroversial, but it is not without challenges. The main question concerns what discrimination is included in the standard description "measures adopted by a Member State the object or effect of which is to treat products coming from other Member States less favourably". ${ }^{44}$ Does this phrase capture only directly discriminatory measures, i.e. de jure discriminatory rules imposing specific requirements on imported goods, or also indirectly discriminatory measures, treating

\footnotetext{
${ }^{40}$ Scotch Whisky, para. 32.

${ }^{41}$ Colruyt, paras. 35-37.

${ }^{42}$ See also AG Bot's opinion in Scotch Whisky, para 63.

${ }^{43}$ See below Chapter 7.

${ }^{44}$ See Trailers, para. 37; Ker-Optika, para. 49.
} 
domestic and imported goods the same de jure but not de facto? ${ }^{45}$ The wording, in particular the "object or effect", might be seen as indicating a broad approach to discrimination, including measures that indirectly favour domestic goods.

We have argued in favour of limiting the use of the non-discrimination principle as part of the application of Article 34 TFEU to directly discriminatory measures, ${ }^{46}$ mainly to simplify the MEQR analysis and avoid overlap. As already discussed, the main advantage of the new MEQR definition in Trailers is the falling order of ease of detection of the three aspects. Direct discrimination is obvious, easy to detect and a clear violation of the fundamental idea of the internal market. Extending the nondiscrimination principle to indirectly discriminatory measures would create unfortunate and unnecessary overlap with the principles of mutual recognition and market access.

Recent case law indicates that the CJEU has limited the reach of the nondiscrimination principle in MEQR cases. ${ }^{47}$ This is illustrated by Bonnarde concerning a French law granting ecological subsidies to vehicles fulfilling certain requirements, one of which being that the registration document should explicitly state that the vehicle was a "demonstration vehicle". ${ }^{48}$ The CJEU concluded that even though the rule in question applied without distinction to both domestic and foreign vehicles it could in practice affect imported vehicles differently, since all Member States might not require the registration document to contain the relevant information. ${ }^{49}$ This appear to be a discussion of indirect discrimination, but the Court then turns to market access, stating that the French rules "may influence the behaviour of consumers and, consequently, affect the access of those vehicles to the market of that Member State". ${ }^{50}$ Consequently, the practical difficulties were regarded as part of the market access discussion rather than the discrimination analysis.

Similarly, in Commission v. Belgium, ${ }^{51}$ the Court eschewed discrimination analysis in favour of market access examination. Here Belgian rules required vehicles to fulfil a roadworthiness test prior to registration, without taking into account a

\footnotetext{
45 These are sometimes also referred to as distinctly and indistinctly applicable measures. To simplify we will use the terms directly and indirectly discriminatory in the following discussion.

${ }^{46}$ Derlén \& Lindholm 2010, pp. 215-217.

${ }^{47}$ A rather particular example, pointing in the other direction, is provided by the CJEU's abovementioned decision in Visnapuu. In this case, the CJEU performed a traditional Keck analysis, including the discrimination test which is part of the Keck doctrine. See Visnapuu, paras. 104-106.

${ }^{48}$ Case C-443/10, Bonnarde v. Agence de Services et de Paiement, EU:C:2011:641, paras. 11-17.

${ }^{49}$ Ibid., paras. 28-29.

${ }^{50}$ Ibid., para. 30.

${ }^{51}$ Case C-150/11, Commission v. Belgium, EU:C:2012:539.
} 
roadworthiness test carried out in another Member State. The inspection applied when the ownership of a vehicle changed and applied to both domestic and imported vehicles. Thus, the rules were de jure non-discriminatory, but it was clear that imported vehicles were specially affected, in the sense that tests carried out in other Member States were not recognised. However, the Court went straight to a market access discussion. A single meaning sufficed for the Court to define the rules as an MEQR: ${ }^{52}$

Therefore, that non-periodic test, inasmuch as it is carried out in addition to roadworthiness tests recently effected in other Member States, the results of which are not recognised, may deter certain interested individuals from purchasing such vehicles coming from other Member States.

\section{Market Access - But What Does It Mean?}

The third and arguably most interesting element of the MEQR definition in Trailers is "[a]ny other measure which hinders access of products originating in other Member States to the market of a Member State". ${ }^{53}$ This test, the market access test, is obviously able to capture measures that directly target the movement of goods across Member States as MEQRs, for example rules making import dependent on authorisation or notification. ${ }^{54}$ In situations like these, the CJEU has upheld a stringent standard when it comes to market access. An example of this is the ANETT case. ${ }^{55}$ The case concerned the Spanish tobacco monopoly system, according to which retail sale of tobacco was limited to authorised retailers. However, the legislation also stated that the retailers had to make their purchases of tobacco from authorised, national wholesalers. The latter was obliged to satisfy requests for tobacco from other Member States, but it could at the very least delay such imports. The retailers were prohibited from importing tobacco products directly from other Member States. The Court concluded that the Spanish rules were neither discriminatory nor product requirements. However, they hindered access to the Spanish market for imported tobacco products as they presented "various

\footnotetext{
52 Commission v. Belgium, para. 51.

53 Trailers, para. 37.

54 See e.g. Case C-472/14, Canadian Oil Company Sweden AB \& Rantén v. Riksåklagaren, para. 44 (national rules requiring importers to register imported chemicals); Audace, para. 67 (national rules requiring authorisation to parallel import veterinary medicinal products).

55 Case C-456/10, Asociación Nacional de Expendedores de Tabaco y Timbre (ANETT) v. Administración del Estado, EU:C:2012:241.
} 
disadvantages" for the authorised retailers. ${ }^{56}$ In particular, the Court pointed to the fact that the tobacco retailers had "no direct, flexible and quick means of meeting the demands of their own customers". ${ }^{57}$ This indicates a significantly lower threshold for market access restrictions as compared to Trailers. In ANETT, delays and inconveniences are deemed sufficient to classify the relevant rule as an MEQR. Presumably, this strict attitude should be understood against the background of the impact on imports, more specifically the fact that the Spanish rule prevented direct imports from other Member States.

A more complicated issue is to what extent the market access test also captures measures that are neither discriminatory, nor product requirements, nor directly affect the ability to import or export goods between Member States. We know from Trailers and Mickelsson that rules on use are capable of failing the market access test, but these decisions left much to be desired in terms of guidance regarding how extensive a rule's effect on market access must be in order to constitute an MEQR. ${ }^{58}$

The Court's case law post-Trailers has done little to clarify how to answer this difficult question. In 2015-2016, the Court reviewed the market-access effect of three national rules preventing retail sale below certain price using three different approaches. In the aforementioned Scotch Whiskey the Court found that the minimum retail price hindered market access and constituted an MEQR. Following the Advocate General's opinion, 59 the CJEU reasoned that "the fact that the legislation at issue in the main proceedings prevents the lower cost price of imported products being reflected in the selling price to the consumer means, by itself, that that legislation is capable of hindering the access". ${ }^{60}$ Thus, the rule hindered market access even though importers and retailers had financial incentives to buy cheap alcohol, including from other Member States.

It seems to follow from Scotch Whiskey that minimum price rules are inherent MEQRs since price competition is such a fundamental element of a competitive and efficient internal market, even if such rules apply equally to all traders and goods regardless of where they are established and produced. This reasoning is not entirely novel: the CJEU acknowledged in Keck that minimum price rules may restrict "the volume of sales of products from other Member States, in so far as it deprives traders

\footnotetext{
${ }^{56}$ Ibid., paras. 32-43.

${ }^{57}$ Ibid., para. 39.

${ }^{58}$ Derlén \& Lindholm 2010, p. 230.

${ }^{59}$ AG Bot's opinion in Scotch Whiskey, paras. 59-60.

${ }^{60}$ Scotch Whiskey, para. 32 (emphasis added).
} 
of a method of sales promotion." ${ }^{\prime 1}$ However, whereas such a rule does not constitute an MEQR according to Keck, it is "by itself" an MEQR according to $S$ cotch Whiskey. This is a rather quick and radical turn-around on behalf of the Court. Only six years earlier, in $L I B R O$, the Court concluded that rules setting fixed retail prices for books could only constitute MEQRs if they have "the effect of treating products from other Member States less favourably". ${ }^{62}$

Scotch Whiskey can be compared to Colruyt where the CJEU found that that the measure in question applied equally to all traders and was "not of such a kind as to prevent access to the Belgian market of tobacco products from another Member State or to impede access any more than it impedes the access of domestic tobacco products" and was therefore not an MEQR. ${ }^{63}$ The difference with the measure in Scotch Whiskey, which also applied equally to all traders and products from all Member States, is not immediately obvious. However, the crucial difference seems to be that in Colruyt the minimum retail price of imported goods was fixed, not in law, but by the importer, and it is thus up to importers to determine if the lower price of imported products will be reflected in the consumer price. ${ }^{64}$

The Court took a slightly different approach in Deutsche Parkinson. Contrary to German fixed-price rules, a German organisation was cooperating with a Dutch pharmacy to give its members bonuses when they imported prescription drugs from the pharmacy. Looking at Scotch Whiskey, decided only ten months earlier, it seems obvious that the national rules in Deutsche Parkinson constituted MEQRs as fixed price regulations function as maximum price regulations, as well as minimum price regulations and that the measure, unlike in Colruyt, concerned state-fixed consumer retail prices. However, the CJEU did not approach the measure as it had in Scotch Whiskey, Colruyt or LIBRO. Instead, the CJEU conducted a more extensive market access analysis where it compared the impact of price fixing on pharmacies established in Germany and in other Member States. The Court found that mailorder pharmacies have a limited ability to compete with traditional pharmacies when

${ }^{61}$ Keck, para. 13. Naturally, the rule in Keck was technically a ban on resale at a loss, but in practice this amounts to a minimum price regulation.

${ }^{62}$ LIBRO, para. 22. See also Alberto Alemanno, "Balancing free movement and public health: The case of minimum unit pricing of alcohol in Scotch Whisky", Common Market Law Review vol. 53 pp. 1037-1064 (2016), at p. 1049.

${ }^{63}$ Colruyt, paras. 38-40 (para. 39 quoted). Similarly, in the area of freedom of establishment the CJEU has concluded that an Italian rule establishing maximum tariffs for lawyers did not prevent market access. Case C-565/08, Commission v. Italy, EU:C:2011:188, paras. 41-55.

${ }^{64}$ Although the Court does not state it, the decision in Colruyt in this regard appears to rely on a wellfunctioning market where price competition between domestically produced and imported goods will be passed on to the consumer, and quite reasonably so. 
it comes to services, that the former can primarily compete with prices, and that price fixing therefore has a greater impact on pharmacies established in other Member States, "a fact which could impede market access for products from other Member States more than it impedes such access for domestic products." ${ }^{65}$ The reasoning in Deutsche Parkinson seems unnecessarily complicated considering the Court's conclusion in Scotch Whiskey that a minimum price rule is "in itself" an MEQR. The only obvious difference between the two cases is the location of the retailers which in Scotch Whiskey were in the same Member State (United Kingdom) and in Deutsche Parkinson in different Member States (Germany and the Netherlands). However, it is unclear why this factual difference would call for a different and under the latter circumstances more lenient market access test.

At the same time, Scotch Whiskey and Deutsche Parkinson are similar in that they take a rather strict approach to the size of the market access restriction necessary in order for a measure to constitute an MEQR. While decisions like Colruyt demonstrate that restricting measures may pass the market access test and consequently not constitute MEQRs, the room for this is narrow and narrower than under Keck.

\section{Proportionality - Has the Honeymoon Ended?}

In Trailers, the CJEU applied the proportionality test in a rather generous manner, particularly with regard to the necessity element of the test. The Court first stated that the Member States enjoyed "a margin of appreciation" when it comes to taking measures to ensure road safety and that the extent of such measures may differ between Member States. ${ }^{66}$ The Court then noted that less restrictive, non-ban measures would be able to achieve the aim of road safety. However, according to the Court, Italy did not have to prove "that no other conceivable measure could enable that objective to be attained under the same conditions" 67 and held "that Member States cannot be denied the possibility of attaining an objective such as road safety by the introduction of general and simple rules which will be easily understood and applied by drivers and easily managed and supervised by the competent authorities." 68

At the time, we were somewhat sceptical about the CJEU's generous approach, which to us seemed like the Court compensating the Member States for the inclusion

\footnotetext{
${ }^{65}$ Case C-148/15, Deutsche Parkinson Vereinigung eV v. Zentrale zur Bekämpfung unlauteren Wettbewerbs eV, paras. 21-27 (para. 26 quoted).

66 Trailers, para. 65.

${ }^{67}$ Ibid., para. 66.

${ }^{68}$ Ibid., para. 67.
} 
of rules on use within MEQRs, and called for a normalization of the proportionality scrutiny. ${ }^{69}$ The fact that there have been few pure rules-of-use cases in the decade that has followed complicates assessing whether this is the case.

However, it is quite clear that the easily-managed-and-supervised approach to necessity used in Trailers is very much still relevant. The CJEU has subsequently applied this standard as part of the justification analysis across the field of free movement and applied to various legitimate aims. ${ }^{70}$ It seems unlikely that the Court would, generally and as a matter of principle, refuse to use that approach in a case solely on the ground that it concerns rules on use.

On the other hand, in other cases concerning MEQRs we can find examples of the CJEU applying a more traditional, i.e. strict, proportionality discussion. For example, in Ker-Optika the Court engaged in a detailed discussion of the Hungarian rules banning sales of contact lenses over the internet, ultimately concluding that the rules were not proportional. ${ }^{71}$ Humanplasma presents a similar image. ${ }^{72}$ The case concerned Austrian rules banning the import of certain blood related productions, if these were not entirely unpaid. The Court recognized the human health concerns of the Austrian government, but still engaged in a detailed discussion regarding proportionality, ultimately finding the Austrian rules excessive in relation to the objective. $^{73}$ The above-mentioned cases Commission v. Poland and Commission v. Lithuania also illustrate a rather strict approach to proportionality. The CJEU found the arguments of the Member States regarding road safety, and the dangers of vehicles with right-hand steering, unconvincing, and pointed to the availability of other. less restrictive, measures. ${ }^{74}$

${ }^{69}$ Derlén \& Lindholm 2010, p. 231.

${ }^{70}$ See for example Case C-400/08, Commission v. Spain, EU:C:2011:172, para. 124 (freedom of establishment and environmental protection, town and country planning and consumer protection); Case C-137/09, Josemans v. Burgemeester van Maastricht, EU:C:2010:774, para. 82 (free movement of services and goods and combating drug tourism); Case C-126/15, Commission v. Portugal, EU:C:2017:504, para. 84 (cigarette excise duty and preventing tax evasion).

${ }^{71}$ Ker-Optika, paras. 57-75.

${ }^{72}$ Case C-421/09, Humanplasma GmbH v. Austria, EU:C:2010:760.

${ }^{73}$ Ibid., paras. 31-45.

${ }^{74}$ Commission v. Poland, paras. 58-65; Commission v. Lithuania, paras. 63-70. The fact that the CJEU pointed out that the vast majority of Member States accepted the use of right-hand steering vehicles is particularly noteworthy. Commission v. Poland, para. 61; Commission v. Lithuania, para. 66. As observed by Barnard, this might indicate a majoritarian approach. Catherine Barnard, The Substantive Law of the EU - The Four Freedoms, 5th edition, Oxford University Press, Oxford 2016, p. 182. 


\section{Conclusions - Chi va piano...}

CJEU decisions on MEQRs rendered over the last ten years provide us with some answers to the questions that lingered after Trailers. First, the three-part definition of MEQRs launched in Trailers does not appear limited to rules on use and other similarly "exotic" types of national measures. While it has not - unfortunately replaced Dassonville's definition of MEQRs, the Court has over the last decade increasingly come to combine the Dassonville formula with the definition presented in Trailers. The impact of Trailers on the doctrine for selling arrangements has been particularly strong. The Court's recent decisions on selling-arrangement-like measures suggest that Keck is in practise obsolete and that at least some measures that would fall outside of that decision's definition of MEQRs now fall within it. The future of the separate product requirement test, and the Cassis de Dijon line of case law, is - somewhat to our surprise - less clear than indicated in Trailers.

Second, there are some indications that the discrimination test in Trailers has been limited to directly discriminatory measures in later case law, while indirectly discriminatory measures are analysed within the market access doctrine. This, we would argue, is a welcome step, simplifying the MEQR definition.

Third, the Court has still offered limited guidance on how to apply the market access limb, including what constitutes a sufficiently great obstacle to market access or how to assess the size of such obstacles. However, judging from the limited guidance offered it appears as if the bar is low. This is particularly true when the rule is closely connected to imports, as demonstrated by ANETT. The only post-Trailers example of the Court finding (or even suggesting) that a relevant national measure did not hinder market access was in Colruyt. This shows that there is still room for measures to fall outside of the MEQR definition under Trailers, making it more limited than the classic Dassonville formula. However, applying a "pure market access test", as the Court did in Scotch Whiskey, ${ }^{75}$ results in a definition of MEQRs that at least for some cases is broader than under Keck.

Fourth and finally, the leeway that the CJEU afforded Member States in the justification analysis in Trailers does not appear to have gone away. On the contrary, it seems that the approach taken by the Court in Trailers has become the new normal when it comes to determining whether obstacles to fundamental freedoms are justified. At the very least, the Court has afforded Trailers-like treatment in a diverse range of cases. On the other hand, the existence of other MEQR judgments, with a more traditional proportionality analysis, makes it difficult to came to a clear conclusion regarding the attitude of the CJEU regarding justification.

${ }^{75}$ Alemanno 2016, pp. 1049-1050. 
If Trailers was a revolution it was clearly a slow and gradual one. A decade later several questions are still left unanswered, and more guidance is needed from Luxembourg. However, given the complexity of the area this is hardly surprising. We remain convinced that Trailers will continue to shape and change the approach to MEQRs in years to come. Slow and steady wins the race. 